\title{
RELEVANSI KEMAMPUAN PENGOLAHAN PERANGKAT LUNAK COREL DRAW 13 DENGAN KUALITAS TAMPILAN DESAIN BUSANA BERFORMAT DIGITAL
}

\author{
Winwin Wiana \\ Program Studi Tata Busana FPTK UPI \\ bahana_jingga@yahoo.co.id
}

\begin{abstract}
Abstrak : Penelitian ini bertujuan untuk mengetahui relevansi antara kemampuan dalam pengolahan perangkat lunak Corel Draw 13, hasil desain busana berformat digital yang dihasilkannya, serta relevansi antara kedua variabel yang diteliti. Populasi dan sampel penelitian ini adalah mahasiswa Paket Manajemen Desain Mode Program Studi Pendidikan Tata Busana Jurusan PKK FPTK UPI angkatan 2005 dan 2006 sebanyak 31 orang. Metode yang digunakan adalah metode deskriptif korelasional, sedangkan pengumpulan data dilakukan dengan melakukan penilaian terhadap tugas pada mata kuliah Komputer Terapan dan tugas pembuatan desain busana berformat digital pada mata kuliah Desain Mode. Data tersebut selanjutnya diolah dengan menggunakan perhitungan/analisis statistik. Hasil penelitian menunjukkan bahwa responden cenderung memiliki kemampuan yang sangat tinggi dalam mengolah perangkat lunak Corel Draw 13, demikian pula halnya dengan kualitas tampilan desain busana berformat digital yang dihasilkannya, sebagian besar berada pada kriteria sangat tinggi. Selanjutnya melalui perhitungan terhadap koefisien determinasi (KD) pada tingkat kepercayaan 95\% dan 99\% diperoleh hasil sebesar $81 \%$. Hasil penelitian tersebut menunjukkan adanya hubungan fungsional yang posistif dan signifikan antara kemampuan pengolahan perangkat lunak Corel Draw 13 dengan kualitas tampilan desain busana berformat digital yang dibuatnya.
\end{abstract}

Kata kunci : Kemampuan pengolahan perangkat lunak corel Draw, kualitas tampilan desain busana berformat digital

\begin{abstract}
This study aims at determining the relevance of skills in processing software Corel Draw 13, digital format fashion design result, as well as the relevance between the two variables under study. Population and sample of this study are 31 students of Fashion Design Management, Fashion Studies Program, PKK FPTK UPI, class 2005 and 2006. The method used is descriptive correlational method. Data collection is conducted by assessing the tasks in Applied Computer courses and digital format fashion design task Fashion Design class. The data is then processed using statistical calculation/analysis. The results show that participants tend to have very high ability in processing software Corel Draw 13. The qualities of digital format fashion design that are created are mostly at very high criteria. In addition, coefficient of determination obtained in level of confidence $95 \%$ and $99 \%$ obtains is $81 \%$. The results indicate that there is a positive and significant functional relationship between the ability of processing software Corel Draw 13 and quality of digital format fashion designs created.
\end{abstract}

Keywords: software Corel Draw processing ability, digital format fashion design quality

\section{PENDAHULUAN}

Pembangunan di Indonesia pada hakekatnya adalah pembangunan manusia seutuhnya, karena kunci pembangunan adalah faktor manusia sebagai unsur paling utama yang memiliki mutu kemampuan tinggi dan mampu mensukseskan pembangunan. Dalam rangka meningkatkan kualitas sumber daya manusia, pendidikan menjadi faktor utama, karena pendidikan jelas berperan 
dalam membentuk peserta didik menjadi aset bangsa, yaitu menjadi manusia produktif yang memiliki tingkat pengetahuan, keterampilan dan etos kerja yang tinggi.

Satu di antara rancangan kebijakan pembangunan pendidikan adalah menyesuaikan sistem pendidikan dengan kebutuhan pembangunan di berbagai bidang yang memerlukan jenis-jenis keahlian dan keterampilan sekaligus meningkatkan produktivitas, kreativitas, mutu dan kualitas kerja. Oleh sebab itu sistem pendidikan yang patut ada adalah yang mempunyai kemapuan menyesuaikan dan mengembangkan diri dalam menghadapi persoalan dalam bidang pembangunan. Salah satu sistem pendidikan yang dapat memenuhi kebutuhan di atas adalah pendidikan teknologi dan kejuruan yang bersifat formal dan diatur berdasarkan ketentuan-ketentuan pemerintah dan mempunyai keseragaman pola yang bersifat Nasional.

Sejalan dengan tuntutan di atas, maka Program Studi Pendidikan Tata Busana Jurusan PKK FPTK UPI sebagai salah satu Lembaga Pendidikan Teknologi Kejuruan, merancang dan menyusun kurikulum berdasarkan kebutuhan dan perkembangan mode di masyarakat yang terus berkembang dan senantiasa memperhatikan nilai-nilai dasar etika keagamaan dan keilmuan, yang dirancang sebagai berikut :

\section{Didesain secara concurent}

2. Berorientasi kepada kebutuhan lapangan

3. Berdasarkan pendekatan keilmuan dan kompetensi

4. Memiliki muatan mata kuliah inti dan mata kuliah pilihan yang dirancang untuk total $150 \mathrm{sks}$

Salah satu indikator keberhasilan pelaksanaan kurikulum adalah dengan ditetapkannya program pengajaran yang berorientasi "Link and Match", yaitu adanya keterkaitan antara kemampuan yang dimiliki peserta didik dengan kebutuhan lapangan kerja. Oleh sebab itu program pengajaran yang diakomodasi oleh mata kuliah-mata kuliah selalu diarahkan untuk pencapaian suatu kompetensi tertentu dengan selalu memperhatikan kebutuhan di lapangan kerja. Paket Manajemen Desain Busana yang dikembangkan dengan satu komitmen untuk 
menghasilkan lulusan yang memiliki kompetensi dalam bidang perancangan busana, baik pada segmen usaha butik, industri garmen maupun pada pengembangan busana-busana dengan karakteristik estetika yang tinggi, berupaya mengembangkan program pengajaran yang berorientasi sepenuhnya pada pencapaiaan tujuan di muka, yang salah satunya diakomodasi oleh Mata Kuliah Komputer Terapan dan Desain Mode.

Mata Kuliah Komputer Terapan memiliki tujuan untuk mengarahkan mahasiswa pada pencapaian kemampuan dalam mengolah berbagai pekerjaan berformat digital, di mana kompetensi tersebut akan sangat bermanfaat dalam memfasilitasi berbagai aktitivitas, baik dalam proses pembelajaran di lingkungan Prodi Pendidikan Tata Busana, maupun pada berbagai bidang pekerjaan, terutama pada era teknologi informasi saat ini. Salah satu dukungan dari keahlian bidang komputerisasi terhadap bidang busana adalah dengan diterapkannya perangkat lunak Corel Draw pada proses perancangan (desain) busana. Aplikasi teknologi digital pada proses pembuatan desain busana dapat menghasilkan satu karya inovatif berkaitan dengan visualisasi, akurasi dan daya kreasi yang tidak terbatas.

Berdasarkan uraian di atas, maka hal ini dijadikan acuan oleh peneliti untuk melakukan penelitian terhadap masalah yang berkaitan dengan "Relevansi Kemampuan Pengolahan Perangkat Lunak Corel Draw 13 dengan Kualitas Tampilan Desain Busana Berformat Digital pada Mahasiswa Paket Manajemen Desain Program Studi Pendidikan Tata Busana Jurusan PKK FPTK UPI”

Konsep mendasar pada sebuah karya rancangan busana adalah lebih dari sekedar karya visual yang dipresentasikan, namun di dalamnya termuat berbagai informasi yang harus dapat dijabarkan oleh berbagai fihak sebagai gambar kerja yang pada akhirnya akan menghasilkan suatu produk busana. Seorang perancang busana (Fashion designer) adalah fihak pertama yang berperan dalam menyajikan suatu desain fashion sebagai gambar kerja/panduan dalam proses produksi selanjutnya. Oleh sebab itu tampilan visual dari desain yang dibuat, harus memuat berbagai karakter yang dapat memberikan informasi seakurat mungkin tentang busana yang akan dihasilkan.

Memasuki awal tahun 1990an dari tahun ke tahun semakin banyak bidang usaha fashion yang memanfaatkan teknologi komputer pada proses perancangan 
busananya, karena dengan teknologi komputer seorang desainer dengan bebas dapat bereksplorasi dan bereksperimen dalam menciptakan desain-desain busana yang inovatif dan dapat mengakomodasi permintaan pasar. Komputer desain adalah suatu jaringan perangkat teknologi yang berkemampuan tinggi dan serba bisa, sehingga seorang desainer yang telah menguasai teknologi komputer dalam proses pendesainan busana, pada umumnya akan mampu menghasilkan dan mewujudkan ide-ide secara lebih cepat dibandingkan bila dikerjakan dengan cara yang lainnya. Hal ini sangat mendukung dalam mewujudkan target produksi dan efisiensi yang harus dipenuhi oleh suatu industri fashion.

Logika digital kerap kali dinilai lebih kaya karena berisi program-program perangkat lunak dari "perpustakaan" pemikir kelas dunia. Sebagai contoh ketika seorang desainer akan mendesain sejenis busana tertentu, maka kumpulan clipart/art work seperti fasilitas jenis serat, tekstur, motif, warna, garis model serta detail model bagian-bagian busana dapat dimanfaatkan. Desainer tinggal membuat beberapa variasi, modifikasi dan membuat berbagai kreasi dari desain yang telah dibuat lebih dulu sesuai kebutuhan. Kehadiran komputer desain dengan berbagai kelengkapannya lambat laun menjadi satu fasilitas yang semakin digemari oleh banyak perancang, karena berbagai kemudahan yang ditawarkan melalui perangkat lunaknya, dapat membantu para desainer dalam menyelesaikan proses perancangan dengan lebih cepat dan hasil yang optimal.

Dengan keahlian para pembuatnya, komputer desain telah dilengkapi dengan berbagai fasilitas untuk membantu para desainer dalam menghasilkan suatu gagasan perancangan yang lebih kompleks dan dapat diformulasi ulang (edit), sehingga desainer tidak perlu mengulang dari awal bila gambar yang dibuat tidak bagus/tidak tepat. Kondisi tersebut pada akhirnya mengubah parameter desainer dalam bekerja, yaitu bila sebelumnya dengan teknik manual seorang desainer cenderung membuat perencanaan terlebih dahulu dalam suatu proses merancang, kemudian setiap tahapan selalu diperhatikan pada aspek teknis dan pelaksanaan yang memungkin akan sangat dibatasi dengan sarana yang tersedia.

Area di mana teknologi komputer digunakan dengan keberhasilan yang besar berada pada penggambaran, telah mengambil alih tempat para penggambar, dan semua perangkat yang dikaitkan dengannya tersedia pada program tersebut. 
Dengan menggabungkan sistem-sistem pada program tersebut serta pada penggambar yang cocok, maka gambar yang baik dapat dihasilkan, atau lebih baik dari yang dilakukan secara manual. Program-program ini memberikan suatu kisaran fasilitas yang luas dan perangkat yang dapat dengan mudah diterapkan, setelah program tersebut dapat dikuasai. Karena kriteria di sini berkenaan dengan penggambaran elemen desain dan akurasi, maka media komputer sangat ideal dalam memberikan suatu keuntungan yang nyata pada kecepatan dan fleksibilitas.

Begitu banyak keunggulan yang dapat ditampilkan dari teknologi digital pada area perancangan busana, namun demikian komputer desain tidak dapat menciptakan gambar secara spontan/instant, karena Sistem-sistem ini berisi sejumlah program yang sangat kompleks, sehingga setiap program perangkat lunak harus dipahami dan dikuasai, kemudian perangkat tersebut dihubungkan untuk membuat suatu pola interaksi diantara fungsi-fungsinya. Ini juga merupakan sebuah proses yang kompleks untuk dapat dipahami dan tak dapat dihindari, bahwa ini akan menyita waktu untuk memperoleh kontrol keseluruhan sistem. Ini berarti bahwa si perancang harus melupakan kegiatan perancangan selama beberapa waktu dan berusaha untuk menguasai sistem tersebut. Kondisi tersebut bagi beberapa perancang "mungkin" merupakan hal yang kurang menyenangkan, namun setelah proses yang tidak menyenangkan ini berakhir, maka proses berkreasi akan menjadi lebih mudah dari sebelumnya bagi si perancang, karena perancang yang dapat menguasai sistem komputer desain memiliki suatu senjata yang lebih lengkap di tangan mereka. ini berarti bahwa mereka dapat mensketsakan rancangan mereka pada komputer dan membuat buku sketsa mereka sendiri di dalamnya. Ikatan ini meningkatkan semua spesifikasi relevan pada sketsa tersebut dan memberikan akses yang mudah pada kepustakaan gaya yang dihasilkan untuk menstimulus diciptakannya gaya-gaya baru sebagai hasil modifikasi dari gaya-gaya lama.

Dalam dunia fashion, perangkat lunak yang dapat digunakan pada proses pendesainan sangatlah luas dan beragam, karena dalam dunia komputer desain terdapat bermacam-macam program pengolahan gambar dan tata letak. Softwaresoftware tersebut mengalami perkembangan yang sangat pesat, hingga dalam 
hitungan bulan terjadi peningkatan versi dari seri yang telah ada, ataupun muncul seri yang baru.

Salah satu perangkat lunak yang banyak dikembangkan untuk membuat desain busana adalah Program Corel Draw. Perangkat lunak ini cukup sederhana dalam pengoperasian, namun memiliki beberapa fasilitas yang dapat menunjang dalam pembuatan desain busana.Corel draw merupakan suatu program yang banyak dipakai oleh praktisi bidang desain grafis. Tampilan iklan-iklan di surat kabar, majalah, desain busana, dan percetakan pada umumnya menggunakan program ini. Program ini dibuat oleh sebuah perusahaan Corel Corp, dengan nama Corel Draw. Program Corel Draw diperkenalkan pada masyarakat awalnya dimulai dari versi ke-1 dengan banyak keterbatasan, namun hasilnya sudah cukup baik pada masa itu dibandingkan dengan program lainnya yang serupa, seperti free hand atau picture maker. Corel Corp saat ini telah membuat versi yang ke 3. Dibandingkan dengan versi-versi sebelumnya, program corel draw 13 memiliki lebih banyak fasilitas, yaitu terdapat tools yang interakif, seperti Flyout Shape Edit, Flyout curve, Flyout zoom, flyout Rectangle, Flyout Object, Flyout Perfect Shapes, Flyout Interactive Tools, Flyout Eyedropper, Flyout Outline, Flyout Fill, Flyout Interactive Fill, fasilitas extrude dengan bevel yang membuat tampilan 3D yang lebih terlihat seperti aslinya, selain dari itu program ini juga mempunyai kemampuan untuk membuat WEB page.

Sistem gambar pada program Corel Draw termasuk pada sistem vector, yaitu suatu sistem penggambaran dengan berdasarkan pada perhitungan matematik. Karakter dari sistem ini adalah memiliki keterkaitan atau soliditas pada bentuk yang dihasilkannya, sehingga bentuk-bentuk tersebut akan selalu terhubung dan tidak akan mengalami perpecahan, misalnya pada pembuatan sebuah garis lurus diperlukan dua buah titik, yaitu di awal dan di akhir, apabila kedua buah titik tersebut di jauhkan maka dengan cara matematis garis akan tetap terbentuk di antara dua titik tersebut tanpa terputus-putus. Program yang menggunakan sistem vektor diantaranya adalah Autocad, CorelDraw dan Freehand.

Program grafis ini begitu besar pengaruhnya terhadap perkembangan desain komputer pada umumnya. Banyak pengguna yang menyatakan bahwa perkembangan Corel Draw telah begitu pesat mempengaruhi perkembangan seni 
grafis digital yang semakin mempesona. Perkembangan software desain grafis telah mempengaruhi pula pandangan tentang seni digital yang baru ini.

Karakteristik yang ditampilkan dari desain busana berformat digital melalui pengolahan gambar menggunakan perangkat lunak CorelDraw berbeda dengan desain busana yang dibuat dengan tangan secara manual. Desain busana berformat digital memiliki visualisasi gambar yang lebih nyata, karena didukung dengan fasilitas penggunaan berbagai karakter pewarnaan seperti pada penggunaan warna datar, warna-warna gradasi, serta penggunaan motif dan tekstur kain yang secara optimal memberikan satu visi tentang produk busana yang akan diwujudkan. Adapun karakteristik dari desain busana berformat digital secara spesifik terkait dengan aspek visualisasi pada :

\section{Efek Pewarna}

Warna yang dihasilkan dari proses editing pada program Corel Draw 13 dapat berupa warna-warna datar, gradasi, dan perpaduan dua warna atau lebih dalam satu gambar, dengan karakter warna yang dihasilkan memiliki keunggulan pada kerataan dan tingkat akurasinya.

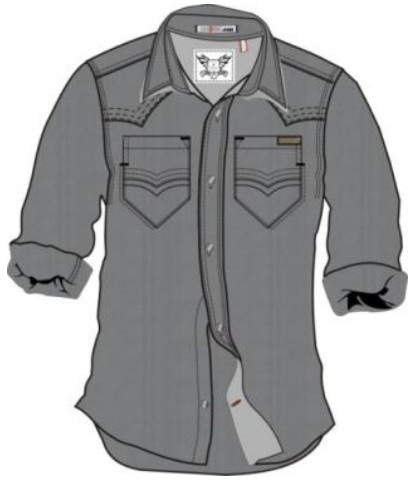

Penggunaan Warna Datar Pada Desain Busana Berformat Digital

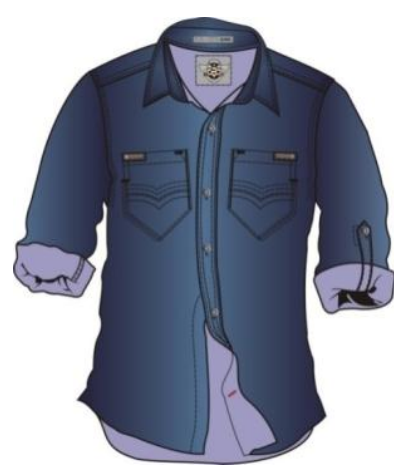

Penggunaan Warna Gradasi Pada Desain Busana Berformat Digital

Gambar 1. Visualisasi Efek Pewarna

\section{Motif}

Visualisasi motif pada desain busana berformat digital dapat dimunculkan dari motif yang dibuat menggunakan program komputer atau menggunakan motif kain yang diperoleh dari proses scanning motif tekstil, sehingga karakteristik tampilan desain lebih nyata. Proses penggunaan motif melalui proses scanning motif tekstil ini merupakan salah satu kelebihan dari desain busana berformat 
digital, karena dapat menunjukan akurasi gambar yang hampir sama dengan produk busana yang akan diwujudkan.
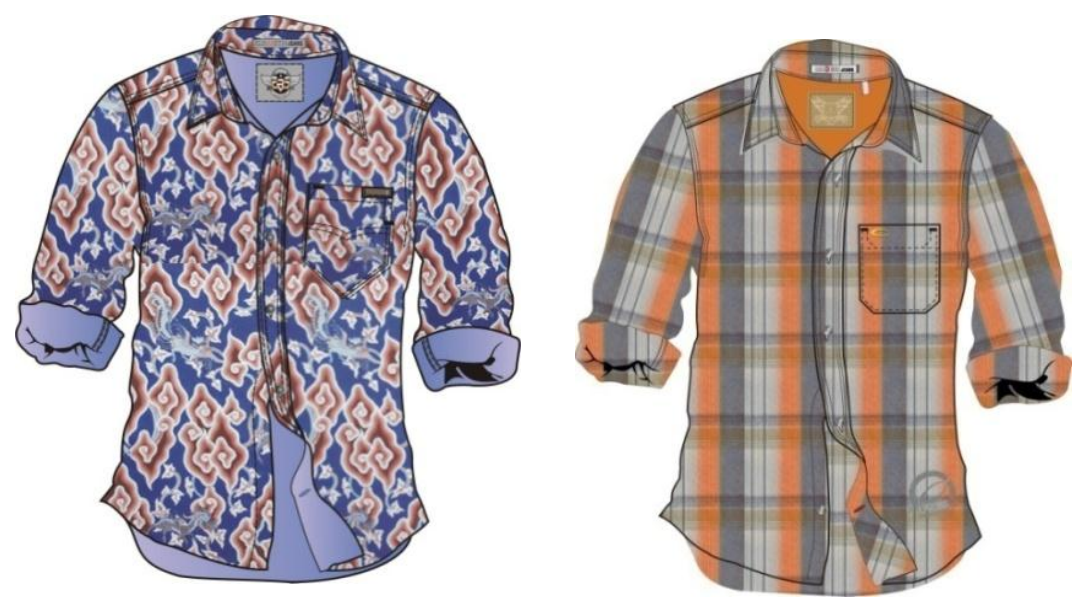

Gambar 2. Pemberian Motif Tekstil (Batik dan Cele) pada kemeja, menghasilan efek viaual yang berbeda

\section{Tekstur}

Sama halnya dengan karakteristik motif, visualisasi karakter tekstur pada desain busana berformat digital memberikan kesan nyata yang ekspresif tentang penggunaan kain pada suatu busana, sehingga tampilan/visualisasi gambar tersebut mendekati produk asli.

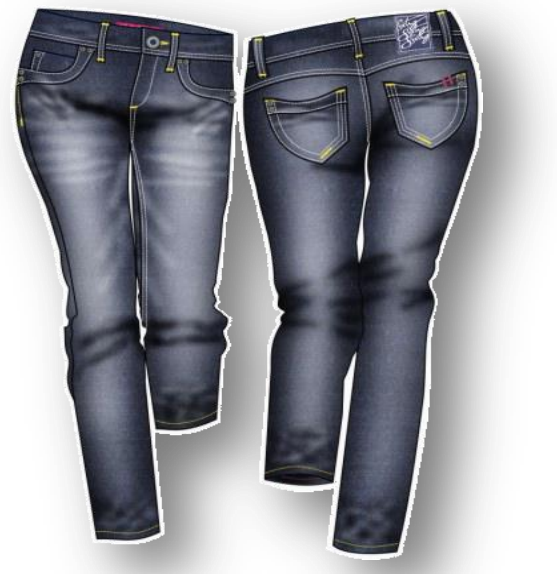

Penggunaan Tekstur Tekstil Denim Melalui Proses Scanning Tekstil, dan Editing lanjut menggunakan Software Photoshop

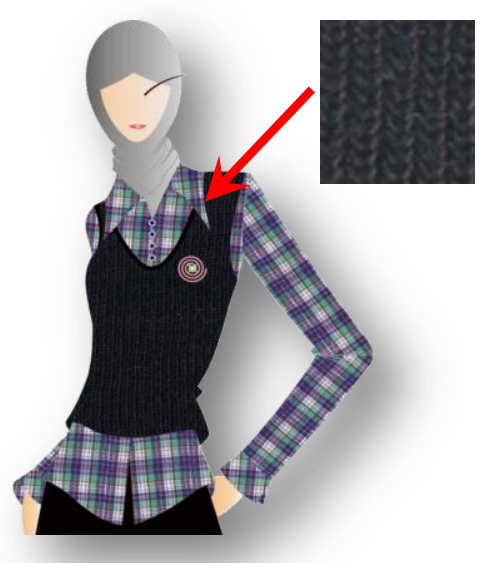

Visualisasi yang Optimal dari Penggunaan Tekstur Tekstil Knitting (Rajut) dan Kain Cele pada Desain Busana Casual

Gambar 3. Visualisasi efek tekstur 
Penguasaan pengolahan perangkat lunak CorelDraw pada pembuatan desain busana berformat digital memberikan banyak keuntungan pada area pembuatan format desain busana, yang diaplikasikan pada desain-desain busana sebagai berikut :

\section{Desain Presentasi (Presentation Drawing)}

Presentation Drawing adalah desain model busana yang digambar selengkap dan sedetail mungkin dengan mencantumkan berbagai aspek yang dapat mendukung performance desain secara keseluruhan. Penyajian desain presentasi perlu dilengkapi dengan keterangan/analisis model, berupa uraian tentang detail model, penggunaan bahan dasar dan bahan pelengkap, jenis busana dan informasi lain yang mendukung. Pada umumnya gambar Presentation Drawing digunakan pada saat desainer mempresentasikan desainnya, atau dipergunakan sebagai master (contoh penawaran) yang diajukan pada proses negosiasi antara calon konsumen (buyer) dengan pihak perusahaan (desainer atau pimpinan perusahaan). Format Presentation Drawing :

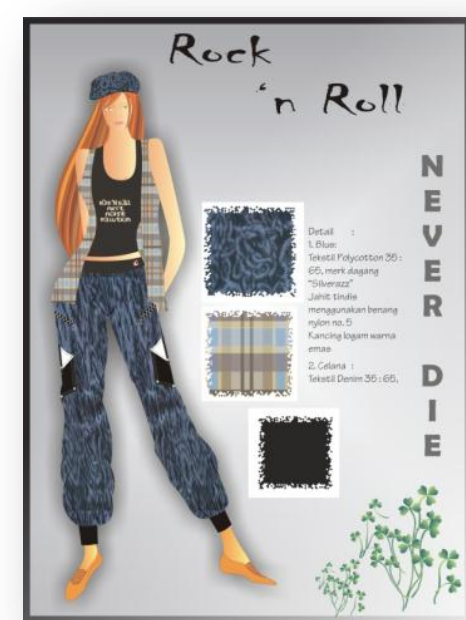

Gambar 4. Format Gambar Presentation Drawing

\section{Desain Produksi (Production Sketching)}

Salah satu media yang sangat membantu dalam membuat sistematika perencanaan produksi pada segmen industri garmen adalah dengan membuat Desain Produksi (Production Sketching). 
Production Sketching merupakan gambar desain busana yang digunakan sebagai pedoman dalam proses produksi pada sebuah industri busana seperti pada industry garmen. Pembuatan desain produksi diproyeksikan sebesarbesarnya untuk meng akomodasi sistem kerja industri yang kompleks dengan kapasitas/volume produksi yang besar. Tujuan penggunaan gambar desain jenis ini adalah untuk menstandarisasi produk pada kisaran standar mutu tertentu sesuai dengan keinginan/pesanan konsumen (buyer)

Untuk kesempurnaan proses produksi pada sebuah industri besar, maka diperlukan gambar production sketching yang lengkap dan jelas. Semua detail pada model busana yang akan diproduksi harus digambar secara lengkap disertai dengan keterangan-keterangan yang mendukung, sehingga akan mudah difahami oleh seluruh team produksi seperti bagian pola, bagian sampel, bagian potong, bagian jahit, bagian finishing, supervisor dan follow up (Merchandiser).

Gambar Production sketching pada umumnya dilengkapi dengan production sheet/worksheet, yaitu lembar kerja yang menguraikan semua keterangan yang diperlukan dalam pembuatan produk busana, seperti jenis bahan yang dipergunakan, warna, corak, ukuran, pelengkap busana, kode produksi, jumlah/kuantitas produksi dan sebagainya, sesuai dengan kebutuhan proses produksi tersebut

Contoh Format Production Sketching.

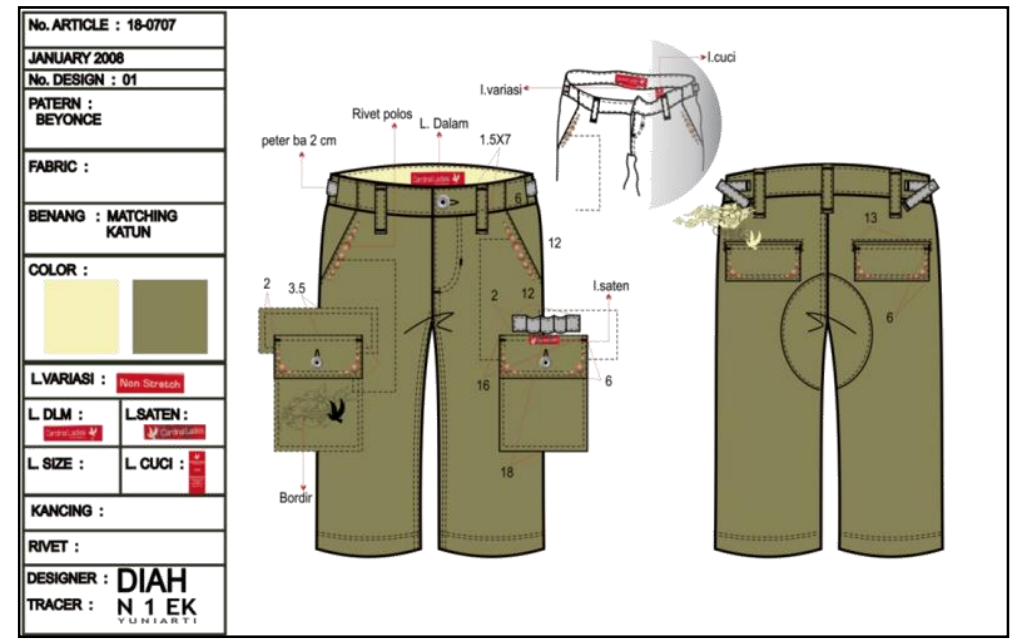

Gambar 5. Format Gambar Production Sketching 


\section{METODE}

Metode yang digunakan dalam penelitian ini adalah metode deskriptif korelasional, yaitu metoda pemecahan masalah yang ada pada masa sekarang dan berpusat pada permasalahan yang aktual, yaitu untuk mengumpulkan, menyusun, menjelaskan dan menganalisis data tentang relevansi kemampuan pengolahan perangkat lunak Corel Draw 13 dengan kualitas tampilan desain busana berformat digital. Pengumpulan data dilakukan dengan melakukan penilaian terhadap tugas pada mata kuliah Komputer Terapan dan tugas pembuatan desain busana berformat digital pada mata kuliah Desain Mode. Data tersebut selanjutnya diolah dengan menggunakan perhitungan/analisis statistik. Populasi dan sampel penelitian ini adalah mahasiswa paket manajemen desain program studi pendidikan tata busana jurusan PKK FPTK UPI angkatan 2005 dan 2006 sebanyak 31 orang.

\section{HASIL PENELITIAN}

Tabel 1 menunjukkan tingkat penguasaan kemampuan pengolahan perangkat lunak Ccorel Draw 13 pada mahasiswa Paket Manajemen Desain Program Studi Pendidikan Tata Busana Jurusan PKK FPTK UPI (Variabel X).

Tabel 1. Tingkat Penguasaan kemampuan Pengolahan Perangkat Lunak Corel Draw 13.

\begin{tabular}{|c|c|c|c|}
\hline Kategori & Rentang & Frekuensi & $(\mathbf{\% )}$ \\
\hline \hline Sangat Tinggi & $\mathrm{n}>87,75$ & 21 & 65,63 \\
\hline Tinggi & $68,25<\mathrm{n}<87,75$ & 8 & 25 \\
\hline Cukup & $48,75<\mathrm{n}<68,25$ & 3 & 9,37 \\
\hline Rendah & $29,25<\mathrm{n}<48,75$ & 0 & 0 \\
\hline Sangat Rendah & $\mathrm{n}<29,25$ & 0 & 0 \\
\hline \multicolumn{2}{|r|}{ Jumlah } & $\mathbf{3 2}$ & $\mathbf{1 0 0}$ \\
\hline
\end{tabular}

Hasil penelitian menunjukkan bahwa kemampuan pengolahan perangkat lunak Corel Draw pada mahasiswa Paket Manajemen Desain Prodi Pendidikan Tata Busana Jurusan PKK FPTK UPI berdasarkan tabel di atas adalah 65,63\% responden berada pada kategori sangat tinggi dan $25 \%$ berada pada kategori tinggi, artinya 8 sampai 21 orang mahasiswa menguasai teknik pengolahan 
perangkat lunak corel draw secara optimal. Responden lainnya yaitu 9,37\% berada pada kategori cukup. Tingkatan kemampuan responden dalam pengolahan perangkat lunak Corel Draw 13 bervariasi, karena dipengaruhi oleh berbagai faktor, diantaranya : bakat, intensitas belajar dan berlatih, kualitas pengajaran dan kemampuan responden dalam belajar.

Gambaran mengenai kemampuan/kualitas pembuatan desain busana berformat digital pada mahasiswa Paket Manajemen Desain Program Studi Pendidikan Tata Busana Jurusan PKK FPTK UPI (Variabel Y) dapat dilihat pada Table 2 berikut :

Tabel 2. Kualitas Pembuatan Desain Busana Berformat Digital

\begin{tabular}{|c|c|c|c|}
\hline Kategori & Rentang & Frekuensi & $(\boldsymbol{\%})$ \\
\hline \hline Sangat Tinggi & $101,25>\mathrm{n}$ & 13 & 40,63 \\
\hline Tinggi & $78,75<\mathrm{n}<101,25$ & 11 & 34,37 \\
\hline Cukup & $56,25<\mathrm{n}<78,75$ & 0 & 0 \\
\hline Rendah & $33,75<\mathrm{n}<56,25$ & 8 & 25 \\
\hline Sangat Rendah & $\mathrm{n}<33,75$ & 0 & 0 \\
\hline \multicolumn{2}{|r|}{ Jumlah } & $\mathbf{3 2}$ & $\mathbf{1 0 0}$ \\
\hline
\end{tabular}

Hasil penelitian menunjukkan bahwa kualitas pembuatan desain busana berformat digital pada mahasiswa Paket Manajemen Desain Program Studi Pendidikan Tata Busana Jurusan PKK FPTK UPI, 40,63 \% berada pada kategori sangat tinggi dan $34,37 \%$ berada pada kategori tinggi, kondisi tersebut dapat diartikan bahwa $68,75 \%$ responden mampu membuat desain busana berformat digital secara optimal, karena mereka memiliki kemampuan yang tinggi dalam membuat desain busana berformat digital. Kondisi lain menunjukkan sebanyak $25 \%$ hasil desain busana berformat digital berada pada kategori rendah, hal ini berarti bahwa sebanyak $25 \%$ responden tidak optimal dalam pembuatan desain busana berformat digital, dengan kata lain kemampuan mereka dalam mendesain busana rendah.

Hubungan fungsional antara kemampuan pengolahan perangkat lunak Corel Draw 13 (Variabel X) dengan kualitas tampilan desain busana berformat digital (Variabel Y) dapat dilihat melalui pengolahan persamaan regresi : $\hat{\mathrm{Y}}=\mathrm{a}+\mathrm{Bx}$ 
Hasil perhitungan persamaan regresi diperoleh: $\hat{\mathrm{Y}}=96,57+1,96 \mathrm{X}$. Penafsiran terhadap persamaan regresi tersebut yaitu bahwa bila terjadi kenaikan satu satuan variabel $\mathrm{X}$ secara bersamaan diikuti oleh kenaikan satu variabel $\mathrm{Y}$ sebesar 1,96 satuan, dengan kata lain jika skor rata-rata kemampuan pengolahan perangkat lunak Corel Draw 13 meningkat satu satuan, maka akan diikuti dengan peningkatan kualitas tampilan desain busana berformat digital sebesar 1,96.

Berikut adalah visualisasi komposisi pengaruh kemampuan pengolahan perangkat lunak Corel Draw 13 terhadap kualitas tampilan desain busana berformat digital pada mahasiswa Paket Manajemen Desain Program Studi Pendidikan Tata Busana Jurusan PKK FPTK UPI.

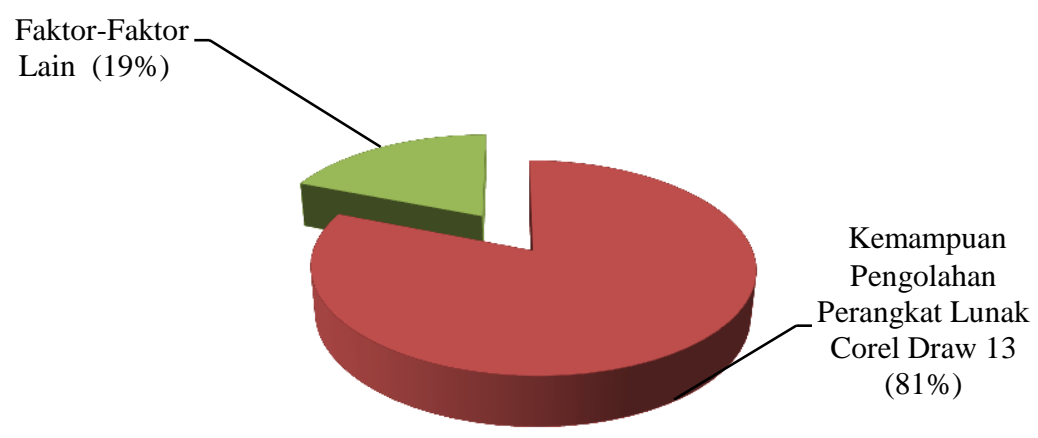

Gambar 6. Komposisi Pengaruh Kemampuan Pengolahan Perangkat Lunak Corel Draw 13 terhadap Kualitas Tampilan Desain Busana Berformat Digital

\section{PEMBAHASAN}

Penelitian tentang Relevansi Kemampuan Pengolahan Perangkat Lunak Corel Draw 13 dengan Kualitas Tampilan Desain Busana Berformat Digital pada Mahasiswa Paket Manajemen Desain Program Studi Pendidikan Tata Busana Jurusan PKK FPTK UPI, menunjukkan bahwa penguasaan pengolahan perangkat lunak corel draw sebagai hasil proses belajar, memberikan sumbangan yang berarti terhadap kualitas pembuatan desain busana berformat digital yang dihasilkannya. Keunggulan yang ditampilkan dari penggunaan perangkat lunak Corel Draw 13 pada proses pembuatan desain busana berformt digital oleh Mahasiswa Paket Manajemen Desain Program Studi Pendidikan Tata Busana 
Jurusan PKK FPTK UPI, diindikasikan dengan peningkatan tampilan visual desain busana yang dihasilkannya, yang memuat karakteristik-karakteristik gambar spesifik yang berbeda dengan hasil pengerjaan secara manual.

Hasil analisis korelasi diperoleh nilai koefisien korelasi sebesar 0,9. Hasil perhitungan ini menunjukkan bahwa kemampuan pengolahan perangkat lunak Corel Draw 13 sebagai Variabel X mempunyai korelasi tinggi yang positif dan signifikan terhadap kualitas pembuatan desain busana berformat digital sebagai Variabel Y.

Perhitungan koefisien determinasi (KD) sebesar $81 \%$, menunjukan bahwa sumbangan penguasaan/kemampuan pengolahan perangkat lunak Corel Draw 13 terhadap kualitas tampilan desain busana berformat digital pada Mahasiswa Paket Manajemen Desain Program Studi Pendidikan Tata Busana Jurusan PKK FPTK UPI adalah sebesar $81 \%$. Sisanya, yaitu sebesar $19 \%$ dipengaruhi faktor lain di luar Variabel yang diteliti. Faktor-faktor yang diduga turut mempengaruhi penelitian ini diantaranya minat, bakat, kreativitas serta motivasi mahasiswa dalam mengembangkan wawasan dan keterampilan dalam pembuatan desain busana berformat digital, lingkungan belajar serta fasilitas pendukung kegiatan belajar.

\section{KESIMPULAN}

Mahasiswa Paket Manajemen Desain Program Studi Pendidikan Tata Busana Jurusan PKK FPTK UPI cenderung memiliki kemampuan yang sangat tinggi dalam mengolah pernagkat lunak Corel Draw 13. Hasil penelitian ini mengandung implikasi bahwa kemampuan tersebut akan menjadi modal yang cukup potensial dalam pencapaian hasil pengolahan desain busana berformat digital yang optimal.

Kemampuan mahasiswa Paket Manajemen Desain Program Studi Pendidikan Tata Busana Jurusan PKK FPTK UPI dalam pembuatan desain busana berformat digital yang diindikasikan melalui optimalisasi tampilan visualnya, berada pada kategori sangat tinggi, yang berarti bahwa tampilan desain busana berformat digital yang dibuat oleh mahasiswa Paket Manajemen Desain 
Program Studi Pendidikan Tata Busana Jurusan PKK FPTK UPI sebagian besar menunjukkan hasil yang optimal.

Hasil penelitian menunjukkan adanya hubungan fungsional yang posistif dan signifikan antara Variabel $\mathrm{X}$ yaitu kemampuan pengolahan perangkat lunak Corel Draw 13 dengan Variabel Y yaitu kualitas tampilan desain busana berformat digital pada mahasiswa Paket Manajemen Desain Program Studi Pendidikan Tata Busana Jurusan PKK FPTK UPI. Hubungan fungsional ini menunjukkan bahwa apabila setiap peningkatan satuan unit kemampuan pengolahan perangkat lunak Corel Draw 13, maka secara bersamaan kualitas tampilan desain busana berformat digital mahasiswa Paket Manajemen Desain Program Studi Pendidikan Tata Busana Jurusan PKK FPTK UPI pun akan mengalami peningkatan.

Perhitungan terhadap koefisien determinasi (KD) pada tingkat kepercayaan $95 \%$ dan $99 \%$ diperoleh hasil sebesar $81 \%$. Hasil perhitungan tersebut menunjukkan bahwa sumbangan penguasaan/ kemampuan pengolahan perangkat lunak corel draw terhadap kualitas tampilan desain busana berformat digital pada Mahasiswa Paket Manajemen Desain Program Studi Pendidikan Tata Busana Jurusan PKK FPTK UPI adalah sebesar 81\%. Sisanya, yaitu sebesar 19\% dipengaruhi faktor lain di luar Variabel yang diteliti. Faktor-faktor yang diduga turut mempengaruhi penelitian ini diantaranya minat, bakat, kreativitas serta motivasi mahasiswa dalam mengembangkan wawasan dan keterampilan dalam pembuatan desain busana berformat digital, lingkungan belajar serta fasilitas pendukung kegiatan belajar.

\section{DAFTAR PUSTAKA}

A. Agung Suharyadi, 1993, Desain Visual Pada Busana, Pasar Minggu, Jakarta.

Arifah A. Riyanto, 1991, Desain Busana, Yayasan Pembangunan Indonesia, Bandung.

Bagas Prasetyowibowo, 1999, Desain Produk Industri, Yayasan Delapan Sepuluh, Bandung.

Goet Puspo, 2000, Teknik Menggambar Mode Busana, Kanisius, Yogyakarta. Guy Bonciepe, 1975, Design for Industrialization, UNIDO ITD 
Michael Hann, 1997, The Geometry of Regular Repeating Patterns, University of Leed England.

Harold Carr \& Barbara Latham, 1994, The Technology of Clothing Manufacture - Second Edition, Blackwell Scientific Publication, London, Edinburg, Boston, Melbourne, Paris, Berlin, Vienna.

Patrick John Ireland, 1982, Fashion Design Drawing And Presentation, Batsford Academic And Education Ltd, London.

Nur Hamid Roeslana Soekada, 1997, Aspek Teknis dalam Pembuatan Garmen, Arena Tekstil, Jakarta.

Patrick Taylor, 1990, Computers in The Fashion Industry, Heinemann Profesional Publishing Ltd - Halley Court, Jordan Hill, Oxford OX2 8EJ.

Robert Blaich, 1993, Product Design and Comparate Strategy, managing the Connection for Comparative Advantages, McGraw - Hill Inc, New York.

Sharon Lee Tate, 1994, Inside Fashion Design, Harper and Row Publisher 